\title{
Transcripts of the genes sacB, amyE, sacC and csn expressed in Bacillus subtilis under the control of the 5' untranslated sacR region display different stabilities that can be modulated
}

\author{
Yannick Pereira, Régis Chambert, Laurence Leloup, † Jean-Pierre Daguer \\ and Marie-Françoise Petit-Glatron
}

\begin{abstract}
Author for correspondence: Marie-Françoise Petit-Glatron. Tel: +331442747 19. Fax: +33144275994.
\end{abstract} e-mail: glatron@ccr.jussieu.fr

Institut Jacques Monod CNRS, Universités Paris 6-7, Laboratoire Génétique et Membranes, Tour 43, 2 place Jussieu 75251, Paris Cedex 05, France

\begin{abstract}
When Bacillus subtilis levanase (SacC), $\alpha$-amylase (AmyE) and chitosanase (Csn) structural genes were expressed under the regulated control of sacR, the inducible levansucrase (SacB) leader region in a degU32(Hy) mutant, it was observed that the production yields of the various extracellular proteins were quite different. This is mainly due to differences in the stabilities of their corresponding mRNAs which lead to discrepancies between the steady-state level of mRNA of SacB and csn on the one hand and amyE and sacC on the other. In contrast to levansucrase mRNA, the decay curves of $\alpha$-amylase and levanase mRNAs obtained by Northern blotting analysis did not match the decay curves of their functional mRNA. This suggested that only a part of the population of the amyE and sacC transcripts was fully translated, while the others were possibly poorly bound to ribosomes and thus were only partially translated or not at all and consequently submitted to rapid endonuclease degradation. This hypothesis was substantiated by the finding that the introduction of a Shine-Dalgarno sequence upstream from the ribosomebinding site in the sacC transcript resulted in a fourfold increase in both the half-life of this transcript and the production of levanase. An additional cause of low-level levanase production is the premature release of mRNA by the polymerase. It was attempted to correlate this event with internal secondary structures of sacC mRNA.
\end{abstract}

Keywords: mRNA decay, exocellular proteins, sacR, $5^{\prime}$ mRNA stabilizer

\section{INTRODUCTION}

With its capacity to secrete numerous extracellular enzymes directly into the culture medium (Priest, 1977), Bacillus subtilis is a potentially efficient expression host for proteins of interest. Extracellular levansucrase $(\mathrm{SacB})$, expressed under the control of its own leader region $(s a c R)$, is overproduced in a $\operatorname{deg} U 32(\mathrm{Hy})$ mutant during the exponential phase of growth (Chambert \& Petit-Glatron, 1984) and represents $5 \%$ of total proteins

\footnotetext{
†Present address: Department of Plant Pathology, University of California, Davis, California 95616, USA.

Abbreviation: SD, Shine-Dalgarno.
}

under conditions of full induction by sucrose. This $s a c R$ leader region has therefore been widely used for the inducible secretion of heterologous proteins during the exponential phase of growth (Joliff et al., 1989; Dion et al., 1989; Wong, 1989; Petit et al., 1990). Surprisingly, the extracellular production of these proteins, including those originating from other bacilli (Joyet et al., 1986), is within one order of magnitude lower than that of levansucrase. For a long time this low level of production was considered to be due to the susceptibility of foreign proteins to extracellular proteases. Recently, two native secreted proteins, $\alpha$-amylase (AmyE) and levanase (SacC), which are normally expressed at a low level during the stationary phase of growth under the control of their own promoter, were expressed in B. subtilis 
under the control of sacR (Leloup et al., 1997, 1999). In the B. subtilis 168 wild-type strain, amyE is controlled by its promoter amyR1 (Yamaguchi et al., 1974) and sacC is the fifth gene of an operon in which the first four genes (levD, levE, levF and levG) encode polypeptides that constitute a minor fructose phosphotransferase system involved in the regulation of levanase expression (Martin-Verstraete et al., 1990). The structural parts of $a m y E$ and $s a c C$ (including the sequence of their own signal peptide) were fused to $s a c R$ and the gene fusions were introduced into the chromosome of a $\operatorname{deg} U 32(\mathrm{Hy})$ mutant. These strains produced $\alpha$-amylase and levanase in the culture medium during the exponential phase of growth in the presence of sucrose as an inducer. Even so, under these conditions the yield was still much lower than that of levansucrase (Leloup et al., 1997, 1999). Pulse-chase experiments indicated that there were no specific bottlenecks in the secretion pathway of $\alpha$-amylase and levanase to account for such differences, since the precursor form of each protein is efficiently processed (Leloup et al., 1997, 1999). Therefore, it was postulated that the mRNA steady-state level controlled by mRNA decay and/or translation mechanisms is adapted to a particular growth phase (Shields \& Sharp, 1987; Saier, 1995).

To test this hypothesis we assessed the transcriptional efficiency of the gene fusions and the stability of the resulting transcripts. This comparative study was enlarged to include chitosanase, a native extracellular protein that is produced at a low level during the exponential growth phase in B. subtilis 168 (Y. Pereira and others, unpublished results). The structural gene $c s n$ was expressed in a $\operatorname{deg} U 32(\mathrm{Hy})$ mutant under the control of the inducible levansucrase leader region $s a c R$. Thus the transcripts of the four different structural genes shared a similar $5^{\prime}$ untranslated region encompassing the translation initiation signals and possessed $3^{\prime}$ $\rho$-independent terminators of very similar calculated free energies. In contrast, the original transcriptional context of these genes is varied, since they are either mono or polycistronic $(s a c C)$, lie on either the leading $(s a c B$ and $a m y E$ ) or the lagging DNA strand (csn and $s a c C$ ) and are expressed during either the exponential ( $s a c B$ and $c s n$ )or stationary ( $a m y E$ and $s a c C)$ growth phase.

Little is known about the mechanism of mRNA degradation in B. subtilis unlike that of Escherichia coli (Coburn \& Mackie, 1999; Régnier \& Arraiano, 2000; Steege, 2000). Three RNases involved in mRNA processing in B. subtilis have been identified: an endonuclease, RNase III (Wang \& Bechhofer, 1997), and two $3^{\prime}-5^{\prime}$ exonucleases, polynucleotide phosphorylase and the yvaJ gene product (Wang \& Bechhofer, 1996; Bechhofer \& Wang, 1998; Oussenko \& Bechhofer, 2000). It is generally considered that most mRNAs are protected against $3^{\prime}$ exonuclease activities by a stable secondary structure at their $3^{\prime}$ end independently from the nucleotide sequence (Higgins et al., 1993), and that degradation is initiated by upstream endonucleolytic cleavage (Bouvet \& Belasco, 1992) that depends mainly on $5^{\prime}$ binding and sliding of endonucleases, although no homologue of the E. coli RNase $\mathrm{E}$ has yet been identified in B. subtilis (Kunst et al., 1997; Condon et al., 1997; Kaberdin et al., 1998). Furthermore, transcripts of Gram-positive bacteria have been shown to contain $5^{\prime}$ motifs that confer stability on heterologous downstream mRNAs (Bechhofer, 1993). Such motifs are the $5^{\prime}$ mRNA stabilizer of the erm genes of B. subtilis (Bechhofer \& Dubnau, 1987; Bechhofer \& Zen, 1989), the 5' polypurine sequence of the B. subtilis SP82 phage (Hue et al., 1995) and the Shine-Dalgarno (SD)-like sequence of the cryIIIA mRNA of Bacillus thuringiensis (Agaisse \& Lereclus, 1996) which form stable complexes with ribosomes in B. subtilis. To test this potentiality further, we introduced a short sequence complementary to the end of the 16S rRNA in different places in the sacR region of the sacC transcript.

We show in this study that differences in the stabilities of the respective mRNAs may account for the differences in the production yield of the four native exoproteins. Moreover, the presence of a $5^{\prime}$ mRNA stabilizer upstream from the RBS of $s a c C$ can lead to an increase in both the steady-state level and the stability of the mRNA and likewise to an increase in the amount of levanase released into the culture supernatant.

\section{METHODS}

Bacterial strains and media. The strains and plasmids used in this work are listed in Table 1. All were derivatives of the degU32(Hy) Bacillus subtilis mutant. Strains were grown at $37^{\circ} \mathrm{C}$ in minimal medium (Chambert \& Petit-Glatron, 1984) supplemented with $1 \%(\mathrm{w} / \mathrm{v})$ glucose and $0.5 \mathrm{mM}$ calcium chloride. Strain GM9804 contained a sacRcsn fusion and strains GM96202, GM96203 and GM96204 contained fusions of $s a c R$ mutants with $s a c C$ as described below.

Construction of sacRcsn fusion and expression of chitosanase. The B. subtilis chitosanase structural gene was identified by analysis of the complete genome sequence (Kunst et al., 1997). An ORF encoding chitosanase (28 kDa) was identified in the $233^{\circ}$ region of the B. subtilis genome. This enzyme shares $36.4 \%$ identity with the chitosanase product of the Streptomyces sp. csn gene (Masson et al., 1994; Parro et al., 1997) and presents the same activity as that assayed using glycol-chitosan as substrate (Tominaga \& Tsujisaka, 1975). The $B$. subtilis structural gene $c s n$ was amplified by PCR with primers csn 1 and csn2, including restriction sites, as indicated in Table 2, from the chromosomal DNA of strain QB112 isolated as described previously (Leloup et al., 1997). The amplified blunt-ended fragment was inserted into the pCR $(+)$ vector at the $S r f I$ site, after appropriate treatment according to the supplier's recommendations (Stratagene). The csn fragment was isolated after digestion with $S p h \mathrm{I}$ and $\mathrm{XhoI}$ and ligated into the $\mathrm{pCR}(+)$ sacR vector pGMC8 (Leloup et al., 1997) digested with the same enzymes. In pGMC8, which was used previously to construct the fusion sacRamyE (Leloup et al., 1997), the SphI site in sacR fragment was created by substituting the original RBS sequence 5'-AAAGGAGACATGAACG-3' with the following sequence: 5'-AAAGGAGGCATGCAACG-3'. The resulting plasmid pGMC12 was used to transform strain E. coli XL-1 Blue. One transformant was selected and the complete sequence of the gene fusion carried by the recombinant plasmid was controlled by sequencing of the double-stranded recombinant DNA with the appropriate 
Table 1. Strains and plasmids

\begin{tabular}{|c|c|c|}
\hline Strain/plasmid & Relevant genotype and phenotype & Source or reference \\
\hline \multicolumn{3}{|l|}{ Strains } \\
\hline QB112 & $\operatorname{degU} 32(\mathrm{Hy}) \operatorname{sacA321}$ & Lepesant et al. (1976) \\
\hline GM96100 & $\operatorname{degU32}(\mathrm{Hy}) \operatorname{sacA321} \Delta s a c R s a c B ; \mathrm{Sp}^{\mathrm{R}}$ & Leloup et al. (1997) \\
\hline GM96101 & $\operatorname{degU32}(\mathrm{Hy}) \operatorname{sacA321} \Delta s a c R s a c B$ sacRamyE; $\mathrm{Km}^{\mathrm{R}} \mathrm{Sp}^{\mathrm{R}} \mathrm{Cm}^{\mathrm{R}}$ & Leloup et al. (1997) \\
\hline GM96201 & $\operatorname{degU32}(\mathrm{Hy}) \operatorname{sacA321} \Delta s a c R s a c B$ sacRsacC; $\mathrm{Km}^{\mathrm{R}} \mathrm{Sp}^{\mathrm{R}} \mathrm{Cm}^{\mathrm{R}}$ & Leloup et al. (1999) \\
\hline GM9804 & 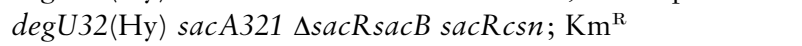 & This work \\
\hline GM96202 & 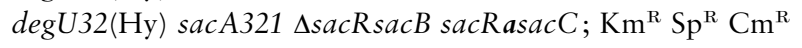 & This work \\
\hline GM96203 & 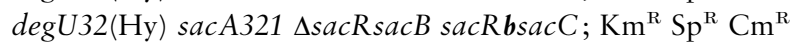 & This work \\
\hline GM96204 & $\operatorname{degU32}(\mathrm{Hy}) \operatorname{sacA321} \Delta s a c R s a c B s a c R c s a c C ; \mathrm{Km}^{\mathrm{R}} \mathrm{Sp}^{\mathrm{R}} \mathrm{Cm}^{\mathrm{R}}$ & This work \\
\hline \multicolumn{3}{|l|}{ Plasmids } \\
\hline pLS50 & B. subtilis sacRsacB region inserted into pJH101; $\mathrm{Cm}^{\mathrm{R}}$ & Steinmetz et al. (1985) \\
\hline pGMK50 & pLS50 derivative; $\mathrm{Km}^{\mathrm{R}} \mathrm{Cm}^{\mathrm{R}} \mathrm{Ap}^{\mathrm{R}}$ & Chambert et al. (1992) \\
\hline pGMK70 & pLS50 derivative; $\mathrm{Km}^{\mathrm{R}} \mathrm{Cm}^{\mathrm{R}} \mathrm{Ap}^{\mathrm{R}}$ & This work \\
\hline pGMK72 & pGMK70 sacRcsn; Km ${ }^{\mathrm{R}} \mathrm{Cm}^{\mathrm{R}} \mathrm{Ap}^{\mathrm{R}}$ & This work \\
\hline $\mathrm{pCR}(+)$ & $\mathrm{Ap}^{\mathrm{R}}$ & Stratagene \\
\hline pGMC8 & $\mathrm{pCR}(+) s a c R ; \mathrm{Ap}^{\mathrm{R}}$ & Leloup et al. (1997) \\
\hline pGMC9 & $\mathrm{pCR}(+) \operatorname{sacR} ; \mathrm{Ap}^{\mathrm{R}}$ & Leloup et al. (1999) \\
\hline pGMC12 & $\mathrm{pCR}(+) \operatorname{sacR} c s n ; \mathrm{Ap}^{\mathrm{R}}$ & This work \\
\hline pGMC15 & $\mathrm{pCR}(+) \operatorname{sacRasacC} ; \mathrm{Ap}^{\mathrm{R}}$ & This work \\
\hline pGMC16 & $\mathrm{pCR}(+) \operatorname{sacR} \boldsymbol{b} s a c C ; \mathrm{Ap}^{\mathrm{R}}$ & This work \\
\hline pGMC17 & $\mathrm{pCR}(+) \operatorname{sacR} c s a c C ; \mathrm{Ap}^{\mathrm{R}}$ & This work \\
\hline
\end{tabular}

Table 2. Oligonucleotides used in this study

\begin{tabular}{|c|c|}
\hline Oligonucleotide $\left(5^{\prime}-3^{\prime}\right)^{*}$ & $\begin{array}{l}\text { Restriction site } \\
\text { at the } 5^{\prime} \text { end }\end{array}$ \\
\hline 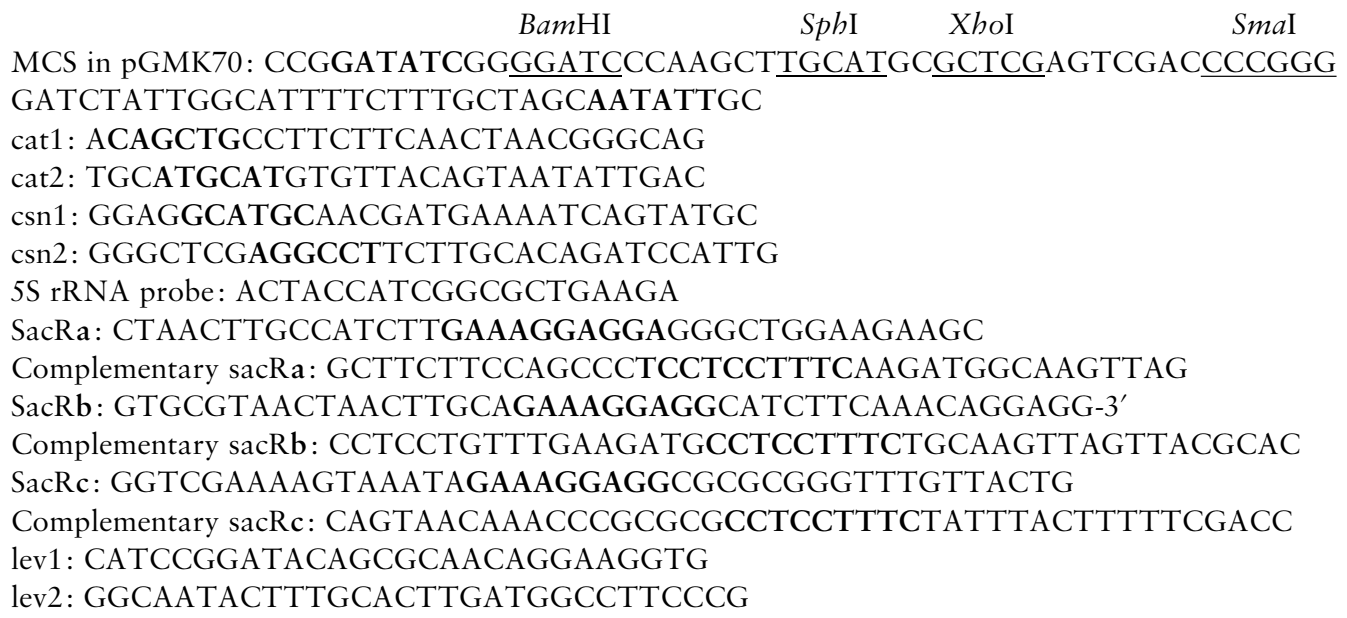 & $\begin{array}{l}\text { EcoRV } \\
\text { SspI } \\
\text { PvuII } \\
\text { NsiI } \\
\text { SphI } \\
\text { StuI }\end{array}$ \\
\hline
\end{tabular}

*Letters in bold refer to restriction sites at the 5 ' end or to sacR modifications.

synthetic oligonucleotides. The BamHI-StuI fragment was purified and ligated into pGMK70 digested with BamHI/SmaI, resulting in pGMK72 (Fig. 1). Strain GM9804, obtained by transformation of B. subtilis GM96100 with pGMK72, overproduces chitosanase in the supernatant of exponentially growing cells in the presence of sucrose. The differential rate of chitosanase production was estimated with reference to protein markers by densitometric analysis of a Coomassieblue-stained SDS-polyacrylamide gel using NIH Image software.

Isolation of total cellular RNA. Bacteria $(5 \mathrm{ml})$ from an 


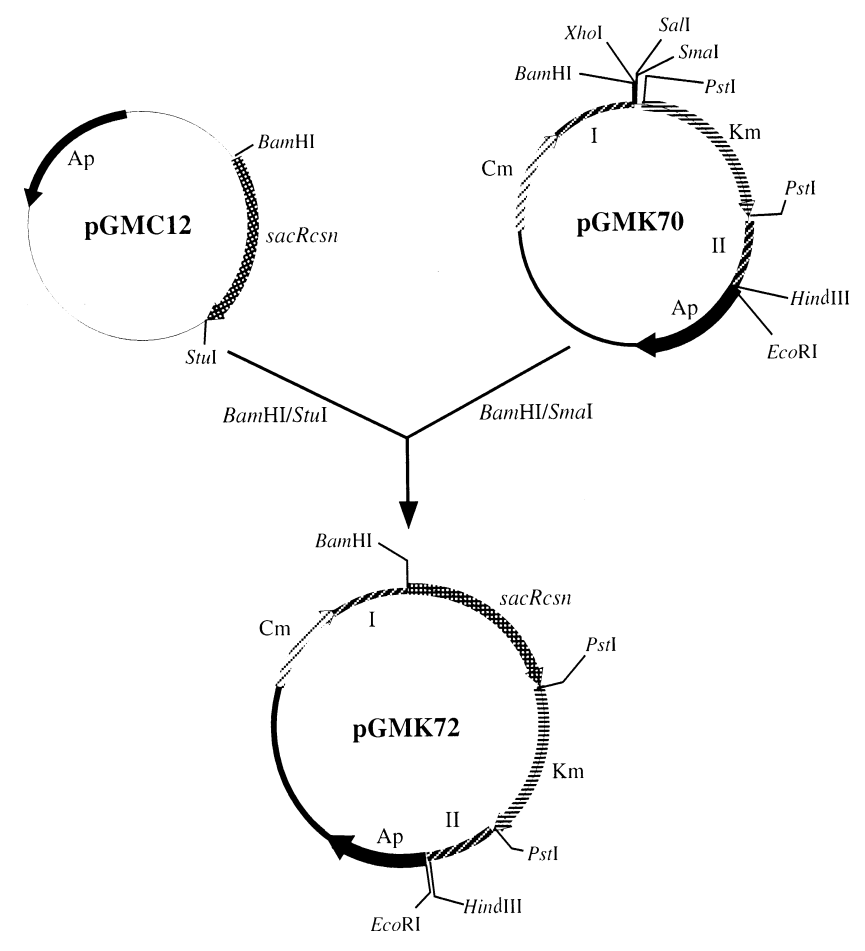

Fig. 1. Construction of the integrative plasmid pGMK72. The region from pBR322 is indicated as a black box and contains the ColE1 origin of replication in E. coli and bla encoding resistance to ampicillin (Ap). Fragments I and II that flank the sacRsacB region in the $B$. subtilis chromosome were introduced on either side of a synthetic oligonucleotide containing cloning sites (Table 2). They correspond to an Nsil-Sspl nucleotide sequence of $673 \mathrm{bp}$ and a Nael-HindIII sequence of $428 \mathrm{bp}$, and to nucleotides 3533914-3534587 and 3536948-3537376 of the $B$. subtilis genome sequence, respectively. $\mathrm{Km}$ indicates the gene encoding kanamycin resistance from pUB110, which was purified from pBest502 (Petit-Glatron \& Chambert, 1992); Cm indicates the cat gene from pC194 (Horionouchi \& Weisblum, 1982), which encodes resistance to chloramphenicol and was cloned by PCR with primers cat1 and cat2 (Table 2).

exponentially growing culture were collected at an $\mathrm{OD}_{600}$ of 1.5 and immediately frozen with liquid nitrogen. Total RNA was isolated essentially as described by Putzer et al. (1992) by vigorous vortexing of the cells in an ice-cold mixture containing 5 g glass beads (100 $\mu \mathrm{m}$ diam.; Braunsciencetec), $5 \mathrm{ml}$ phenol, $1 \mathrm{ml}$ chloroform, $0 \cdot 2 \%(\mathrm{w} / \mathrm{v}$ ) bentone (Bentone MA; Rheox) and $0 \cdot 2 \%(\mathrm{w} / \mathrm{v})$ SDS. After phenol and chloroform extractions of the aqueous phase, followed by a 2-propanol precipitation and $70 \%(\mathrm{v} / \mathrm{v})$ ethanol washing of the pellet, RNA was resuspended in an appropriate volume of diethylpyrocarbonate-treated water.

mRNA half-life measurements. Rifampicin $\left(100 \mu \mathrm{g} \mathrm{ml}^{-1}\right.$ final concentration) was added to exponentially growing cultures at an $\mathrm{OD}_{600}$ of $1 \cdot 5$. Aliquots of $5 \mathrm{ml}$ culture suspension were collected at intervals and immediately frozen in liquid nitrogen. RNAs were prepared as described above and mRNA half-lives were determined after Northern blotting with labelled probes as follows. RNA bands were revealed by phosphor-imaging and relative amounts of mRNA at each time quantified using ImageQuant software (Molecular Dynamics). The kinetic data of mRNA decay were analysed by

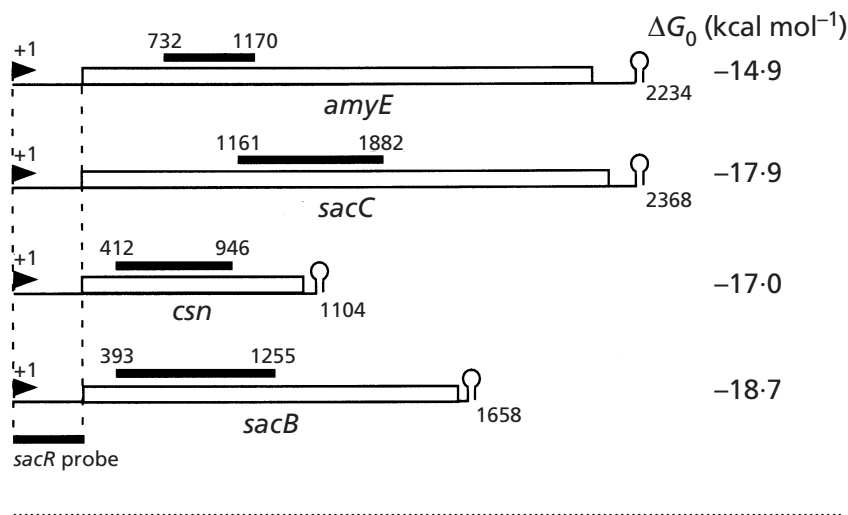

Fig. 2. Free energies $\left(\Delta G_{0}\right)$ of $3^{\prime}$ end $\rho$-independent terminators of the amyE, sacC, csn and sacB transcripts, and probes used in Northern blotting experiments. The fragments corresponding to specific probes (thick black lines) used in the Northern blotting experiments and their lengths are indicated. Nucleotides are numbered from the transcription start $(+1)$. $\Delta G_{0}$ values were estimated using the MFOLD program (Zuker et al., 1999).

non-linear least squares fitting to the sum of exponentials (SigmaPlot curve fitter program):

$(m R N A)_{t}=\sum_{i=1}^{n}\left(m R N A^{0}\right)_{i} \cdot e^{-\lambda_{i} t}$

where $\left(m R N A^{0}\right)_{\mathrm{i}}$ is the initial amount of species $i$, and $\lambda_{\mathrm{i}}$ is the apparent rate constant of the species $i$ decrease. Two models were proposed, a monophasic decay $(i=1)$ or a biphasic decay $(i=2)$. The model which fitted the data with the minimum deviation in each case was retained as being the more valid.

Northern blotting. Total RNA samples (5 or $10 \mu \mathrm{g}$ ) were separated by electrophoresis on agarose gels under the conditions described by Ausubel et al. (1994) and then transferred onto a positively charged polyamide membrane (Nytran + ; Schleicher \& Schuell) in $20 \times$ SSC using a vacuum blotter (Hybaid). Hybridization with the probes described in Fig. 2 was carried out in a solution containing $5 \times$ SSC $(1 \times \mathrm{SSC}$ is $150 \mathrm{mM} \mathrm{NaCl}, 15 \mathrm{mM}$ sodium citrate, $\mathrm{pH} 7)$, $5 \times$ Denhardt's solution, denatured salmon sperm DNA $\left(100 \mu \mathrm{g} \mathrm{ml}^{-1}\right.$ final concentration) and $1 \%(\mathrm{w} / \mathrm{v})$ SDS in $50 \%$ $(\mathrm{v} / \mathrm{v})$ formamide at $42{ }^{\circ} \mathrm{C}$, overnight. Labelling of the probes was performed either by random priming (Megaprime; Amersham) and $\left[\alpha^{-33} \mathrm{P}\right] \mathrm{dATP}$ or with T4 polynucleotide kinase and $\left[\gamma_{-}{ }^{33} \mathrm{P}\right] \mathrm{dATP}$. In addition to the initial quantification of the total RNA by spectrophotometric measurements before electrophoresis on agarose gel, 5S rRNA, used as an internal control for standardization of the RNA samples, was probed with a $5^{\prime}$ end-labelled oligonucleotide (Table 2), which anneals to the $5 \mathrm{~S}$ rRNA between nucleotides 59 and 78. Co-migration with a molecular mass marker mixture (9488-363 nt RNA molecular mass markers; USB) made it possible to estimate the length of the transcripts. RNA bands were revealed by phosphor-imaging and quantified with ImageQuant software.

$\alpha$-Amylase and levanase activity assays. $\alpha$-Amylase activity was assayed at $37^{\circ} \mathrm{C}$ using $p$-nitrophenylmaltotrioside as a substrate (bioMérieux) as described previously (Leloup et al., 1997). Levanase activity was assayed using uniformly labelled $\left[{ }^{14} \mathrm{C}\right]$ levan as substrate (Leloup et al., 1999). 

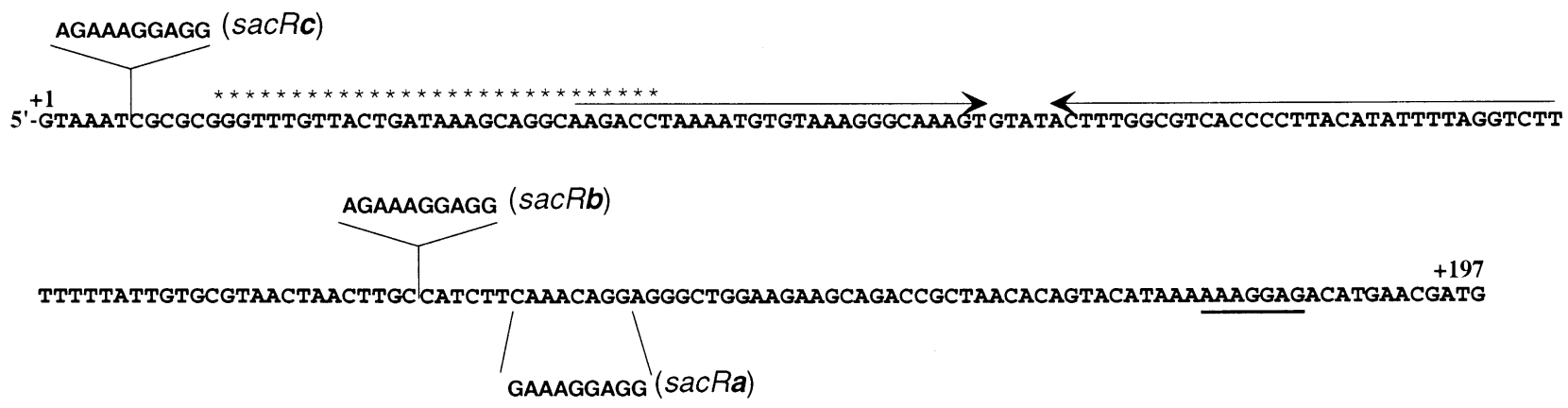

Fig. 3. Schematic representation of the $5^{\prime}$ untranslated region, $s a c R$, from the start of transcription. Mutations in sacR, sacRa, sacRb and sacRc, are indicated. The nucleotides labelled with asterisks represent the antiterminator RNA sequence and the inverted arrows represent the transcription terminator. The putative SD sequence is underlined.

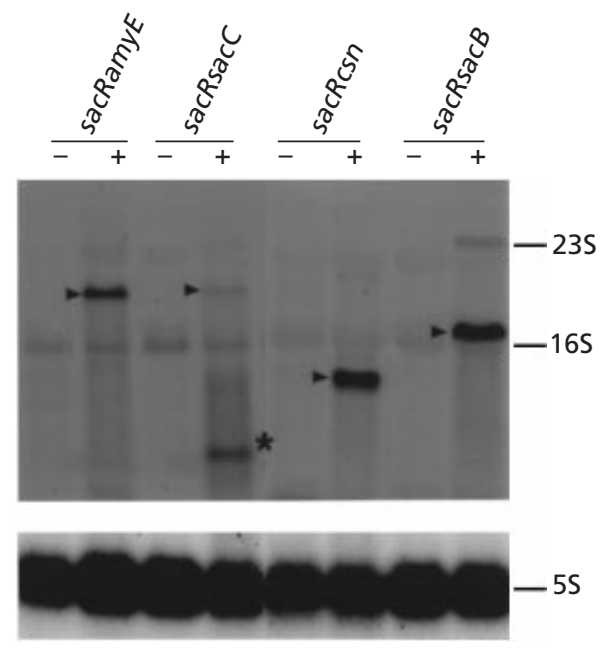

Fig. 4. Northern blotting analysis of total RNA extracted from strains producing $\alpha$-amylase (GM96101), levanase (GM96201), chitosanase (GM9804) and levansucrase (QB112) under the control of sacR. Cells were grown in minimal medium in the presence $(+)$ or absence $(-)$ of sucrose. Samples of the culture were withdrawn at an $\mathrm{OD}_{600}$ of 1.5 , immediately frozen in liquid nitrogen and then treated as described in Methods. Ten micrograms of each RNA preparation was analysed by Northern blotting. Hybridization was done with a ${ }^{33}$ P-labelled sacRspecific probe. Migration of the $23 \mathrm{~S}$ (2928 nt) and 16S (1553 nt) rRNAs is indicated on the right. The short transcript of sacC is labelled with an asterisk.

sacR-directed mutagenesis. Plasmid pGMC9, containing the $s a c R$ sequence with a minor modification (Leloup et al., 1999), was used to introduce a $5^{\prime} \mathrm{mRNA}$ stabilizer sequence by the
Quick change site-directed mutagenesis method (Stratagene) with complementary oligonucleotides (Table 2) to create, by substitution ( $s a c R \boldsymbol{a})$ or insertion ( $s a c R \boldsymbol{b}$ and $s a c R \boldsymbol{c})$, a sequence 5'-GAAAGGAGG-3' at various positions as shown in Fig. 3. This gave pGMC15, pGMC16 and pGMC17 containing the $s a c R a, s a c R b$ and $s a c R c$ mutant fragments, respectively. The structural gene of $s a c C$ was fused to the different $s a c R$ fragments. The resulting $s a c R s a c C$ fusions were controlled by sequencing, ligated into pGMK50 and used to transform strain GM96100 as described previously (Leloup et al., 1997), giving strains GM96202, GM96203 and GM96204, respectively.

\section{RESULTS}

The production of SacB, SacC, AmyE and Csn, when their corresponding genes are expressed under the control of sacR, correlates with the steady-state level of their mRNAs

Strains GM96101 and GM96201, which express sacRamyE and sacRsacC gene fusions, were constructed as described previously (Leloup et al., 1997, 1999). The construction of strain GM9804 expressing sacRcsn is described in Methods. Northern analyses of the cellular RNAs of these strains growing exponentially in the presence or absence of sucrose were performed in parallel to that of strain QB112 producing levansucrase $(\mathrm{SacB})$ using either the $5^{\prime}$ sacR probe for hybridization in the $5^{\prime}$ region of the transcripts or internal probes of the respective genes (Fig. 2). Transcripts of each gene were synthesized when the strains were cultivated in the presence of sucrose (Fig. 4). These transcripts were of the expected lengths (about 2200, 2400, 1100 and

Table 3. Production of $B$. subtilis exoproteins and steady-state levels of their mRNA

\begin{tabular}{|c|c|c|c|c|}
\hline Protein & $\begin{array}{l}\mu \mathrm{g}(\mathrm{mg} \text { total } \\
\text { protein })^{-1}\end{array}$ & $\begin{array}{c}\mathrm{pmol}(\mathrm{mg} \\
\text { total protein })^{-1}\end{array}$ & $\begin{array}{c}\text { Ratio to } \\
\text { levansucrase }\end{array}$ & $\begin{array}{l}\text { mRNA steady-state level } \\
\text { ratio to levansucrase mRNA }\end{array}$ \\
\hline Levansucrase & $52 \cdot 5$ & $1 \cdot 05$ & $1 \cdot 00$ & $1 \cdot 00$ \\
\hline$\alpha$-Amylase & $31 \cdot 2$ & $0 \cdot 45$ & $0 \cdot 43$ & $0 \cdot 46$ \\
\hline Levanase & $6 \cdot 9$ & $0 \cdot 09$ & $0 \cdot 09$ & $0 \cdot 13$ \\
\hline Chitosanase & $21 \cdot 2$ & $0 \cdot 77$ & $0 \cdot 74$ & $0 \cdot 98$ \\
\hline
\end{tabular}



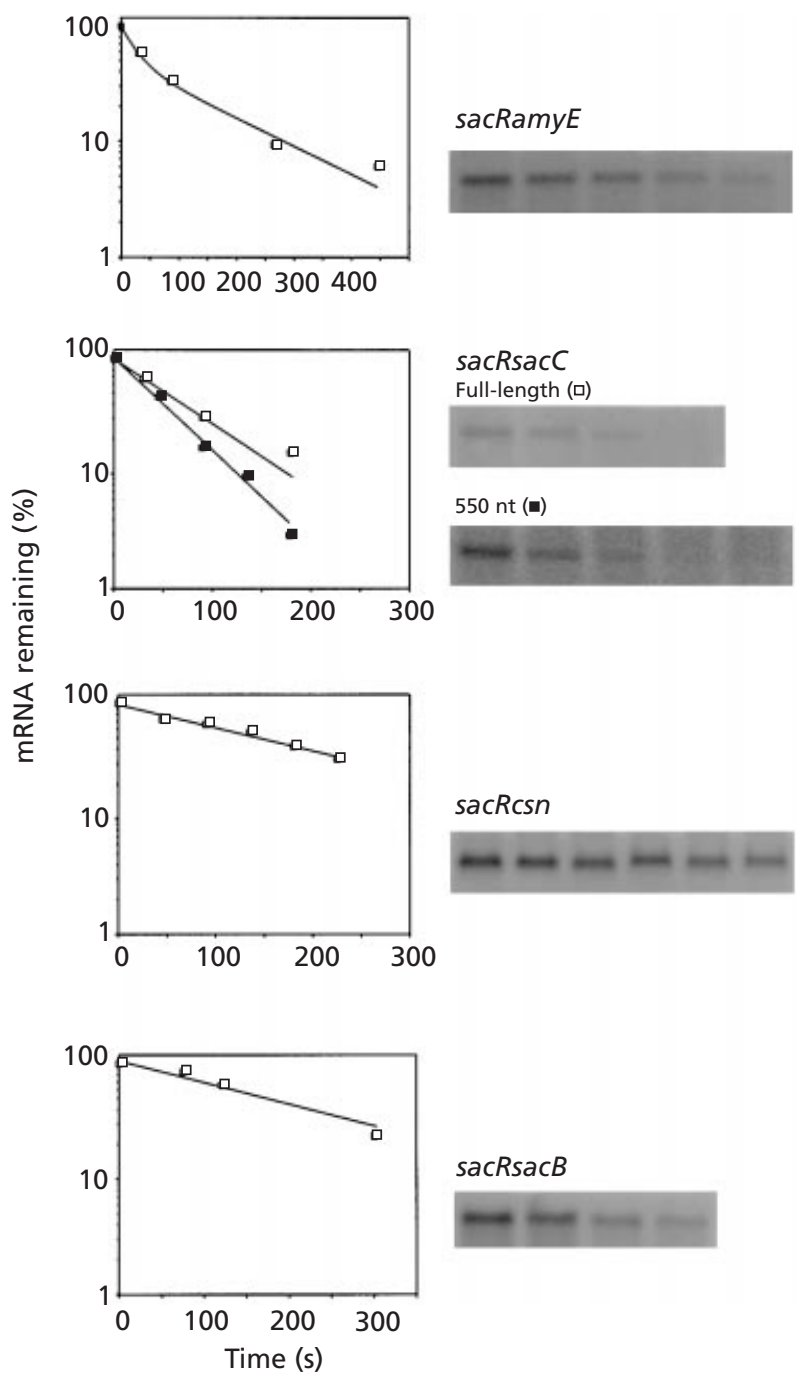

Fig. 5. Kinetic decay of the mRNAs transcribed from amyE, sacC, csn and sacB. Cells were grown in the presence of $60 \mathrm{mM}$ sucrose. Total RNAs were prepared from samples withdrawn at the indicated times starting $45 \mathrm{~s}$ after the addition of the transcription inhibitor. The gels were loaded with $10 \mu \mathrm{g}$ RNA per lane. Northern blotting analysis was performed with genespecific probes and/or the $s a c R$ probe. A representative Northern blotting experiment is shown here with the curve of mRNA decay obtained from SigmaPlot curve fitting treatment as described in Methods.

$1650 \mathrm{nt}$, for $a m y E, s a c C, c s n$ and $s a c B$, respectively), in agreement with the previously determined site of transcription initiation in the $s a c R$ leader sequence (Shimotsu \& Henner, 1986) and generated by transcriptional antitermination at the terminator structure present in sacR (Crutz et al., 1990). A short additional transcript which hybridized only with the $5^{\prime}$ sacR probe was observed in the case of sacC (Fig. 4); it might have been the result of either early transcription termination or degradation. The size of this $3^{\prime}$ truncated transcript was evaluated to be about $550 \mathrm{nt}$ by electrophoresis on an acrylamide gel (Ausubel et al., 1994) and by Northern blotting using the sacR probe (not shown). This point will be discussed later.

Quantification of the labelled bands indicated that the steady-state levels of $s a c B$ and $c s n$ transcripts were similar, whereas amyE and sacC (full-length) levels were 46 and $13 \%$, respectively, of that of sacB. The mRNA levels are, thus, well correlated to the extracellular production of the corresponding proteins (Table 3). The reasons for such a difference in the mRNA steady-state levels could be attributed to differences in either the transcriptional efficiencies of the various genes or their mRNA stability. We therefore analysed the kinetics of decay of these messengers.

\section{Comparison of the kinetics of mRNA decay from Northern blotting analysis with the kinetics of functional mRNA decay}

Stability analysed by Northern blotting. The kinetics of mRNA decay were studied under the same conditions for the four RNA preparations after inhibition of transcription initiation. RNA preparations were analysed by Northern blotting and hybridized with $3^{\prime}$-specific probes and/or the $5^{\prime}$ sacR probe (Fig. 5). The data obtained from the quantification of the bands on the Northern blot from three independent experiments were analysed as mono or biphasic exponential decay with the SigmaPlot curve fitter program. The results (Table 4) show that levansucrase and chitosanase mRNA decays are monophasic events displaying the same time constant. The decays of full-length and short transcripts of sacC appear to be monophasic; both transcripts are more unstable than $s a c B$ and $c s n$ mRNAs.

The decay of amyE mRNA best fitted a biphasic event, suggesting that two mRNA populations, with quite different stabilities, are present in approximately equivalent proportions under steady-state conditions (Fig. 5). It is worthwhile noting that the time constant of the decay of the more stable of the two is close to those of $s a c B$ and $c s n$ transcripts.

Stability of functional mRNAs. The functional mRNA decay was evaluated by quantifying the increase in the amount of enzyme synthesized after inhibition of transcription initiation. The half-life of levansucrase functional mRNA determined previously for the same strain under the same growth conditions (Chambert \& Petit-Glatron, 1984) was evaluated at $100 \pm 7$ s. A similar approach was experimentally suitable for AmyE and SacC, but not for Csn, due to the poor sensitivity of the assay method of this enzyme (Tominaga \& Tsujisaka, 1975). Our results (Fig. 6a, b) show that the functional mRNA decay of sacRamyE and sacRsacC constructs fitted with monophasic events. Their half-lives were estimated to be $103 \pm 21$ and $129 \pm 18 \mathrm{~s}$, respectively. For $\alpha$-amylase, the value of the functional half-life (103 s) was close to that of the half-life of the more stable transcript species (Fig. 5) determined by direct measurement by Northern blotting. For levanase, the value was much higher than that of the full-length mRNA. 
Table 4. Half-lives of sacRamyE, sacRsacC, sacRcsn and sacRsacB mRNAs

\begin{tabular}{|c|c|c|c|c|c|c|}
\hline \multirow[t]{3}{*}{ mRNA } & \multicolumn{2}{|c|}{ Single exponential } & \multicolumn{4}{|c|}{ Double exponential } \\
\hline & \multirow[b]{2}{*}{$\begin{array}{l}\text { Time constant } \\
10^{2} \times k\left(\mathrm{~s}^{-1}\right)\end{array}$} & \multirow[b]{2}{*}{ Half-life (s) } & \multicolumn{2}{|c|}{ Fast phase } & \multicolumn{2}{|c|}{ Slow phase } \\
\hline & & & $\begin{array}{l}\text { Time constant } \\
10^{2} \times k_{1}\left(\mathrm{~s}^{-1}\right)\end{array}$ & Half-life (s) & $\begin{array}{l}\text { Time constant } \\
10^{2} \times k_{2}\left(\mathrm{~s}^{-1}\right)\end{array}$ & Half-life (s) \\
\hline sacRamyE & - & - & $3 \cdot 57 \pm 1 \cdot 29$ & $19 \pm 7$ & $0 \cdot 56 \pm 0 \cdot 15$ & $124 \pm 34$ \\
\hline sacRsacC full-length & $1 \cdot 30 \pm 0 \cdot 04$ & $53 \pm 2$ & - & - & - & - \\
\hline sacRsacC short transcript & $1 \cdot 83 \pm 0 \cdot 08$ & $38 \pm 2$ & - & - & - & - \\
\hline $\operatorname{sacRcsn}$ & $0 \cdot 46 \pm 0 \cdot 04$ & $151 \pm 13$ & - & - & - & - \\
\hline $\operatorname{sacR} s a c B$ & $0 \cdot 5 \pm 0 \cdot 11$ & $139 \pm 31$ & - & - & - & - \\
\hline
\end{tabular}

\section{Stabilization of the sacRsacC transcript}

The results obtained from the analysis of mRNA stability indicated that a similar $5^{\prime}$ untranslated region is not sufficient to confer identical stability on the downstream transcript. Furthermore, comparison of the apparent biphasic decay of total amyE mRNA with the monophasic decay of the functional transcript suggested that a significant proportion of the amyE transcript is not ribosome-bound and is consequently subjected to rapid degradation. This part might be so great in the case of the sacC (full-length) transcript that mRNA decay appears as a monophasic event. One can thus ask whether an increase in the potential of mRNA to bind to ribosomes in turn increases the mRNA stability. We investigated whether insertion of a $5^{\prime}$ mRNA stabilizer has such an effect, as previously suggested by Bechhofer \& Dubnau (1987), with the sacRsacC fusion for two reasons: first, the mRNA has the lowest half-life of all the transcripts studied here, making a potential detection of changes in the stability easier and, second, it should make it possible to determine the status of the short sacC transcript. We therefore introduced as a $5^{\prime}$ mRNA stabilizer, a sequence analogous to the SD element whose bases pair with the $3^{\prime}$ end of the $16 \mathrm{~S}$ rRNA subunit. Three mutants were constructed as described in Methods (Fig. 3). The mutant strains were grown in parallel with the reference strain (GM96201) under the same conditions as before. Total cellular RNA was extracted at various times after inhibition of transcription initiation and probed with the $5^{\prime} s a c R$ fragment. Two discrete bands were observed in the Northern blot of each mutant strain (Fig. 7), corresponding to the full-length and the short transcripts also found in the reference strain (about 2200 and $550 \mathrm{nt})$. The decays of the two mRNA species both follow monophasic kinetics. The effects of the $5^{\prime} \mathrm{mRNA}$ stabilizer on the longevity of the sacRsacC transcripts are summarized in Table 5. A significant increase in the half-life of the $s a c C$ full-length transcript was observed in all mutant strains. The highest values were obtained in strains GM96202 and GM96203 in which the additional SD sequences are close (34 and $52 \mathrm{nt}$, respectively) to the RBS. We found that the steady-state levels of the sacRasacC, sacRbsacC and sacRcsacC mRNAs, evaluated under the same conditions as sacRsacC mRNA taken as reference, are in direct correlation with their decays (Table 5). The production of levanase in the supernatants of the three mutant strains was increased fourfold in strain GM96202 only, while it remained unchanged in GM96203 and decreased by $45 \%$ in GM96204. The relative amount of the short transcript was approximately the same in the three mutants and the reference strain. Oligonucleotide probes lev1 and lev2 (Table 2) were synthesized to determine the location of the $3^{\prime}$ end of the short transcript. Probe lev1, complementary to the nucleotides 464-492, hybridized with the four short transcripts, whereas lev2, complementary to nucleotides 596-625, did not (not shown).

\section{DISCUSSION}

Levansucrase, $\alpha$-amylase, levanase and chitosanase, four native extracellular proteins of $B$. subtilis, expressed under the control of the levansucrase $5^{\prime}$ untranslated leader region, $s a c R$, are produced at very different levels in the culture supernatants.

Measurements of the steady-state level and stability of the mRNAs of the four proteins also indicated differences. Whether these differences could be caused by the minor modifications introduced in the RBS spacer regions of $s a c R$ in the various constructs should be discussed. First, the sacRamyE transcript has a shorter half-life than sacRcsn and the production of $\alpha$-amylase is lower than that of chitosanase, although the two transcripts possess identical spacer regions (length and base sequence). Second, in contrast, sacRsacB and sacRcsn transcripts, which show two differences (one substitution and one insertion) in their spacer region, present no significant differences in their stability, and the production of chitosanase and levansucrase is similar under the same conditions. Finally, during the revision process of the manuscript, we constructed a second sacRsacB fusion, based on the $s a c R$ fragment of plasmid pGMC9 (Leloup et al., 1999), which was also used to construct the sacRsacC gene fusion. We observed an identical production of levansucrase by the strain 

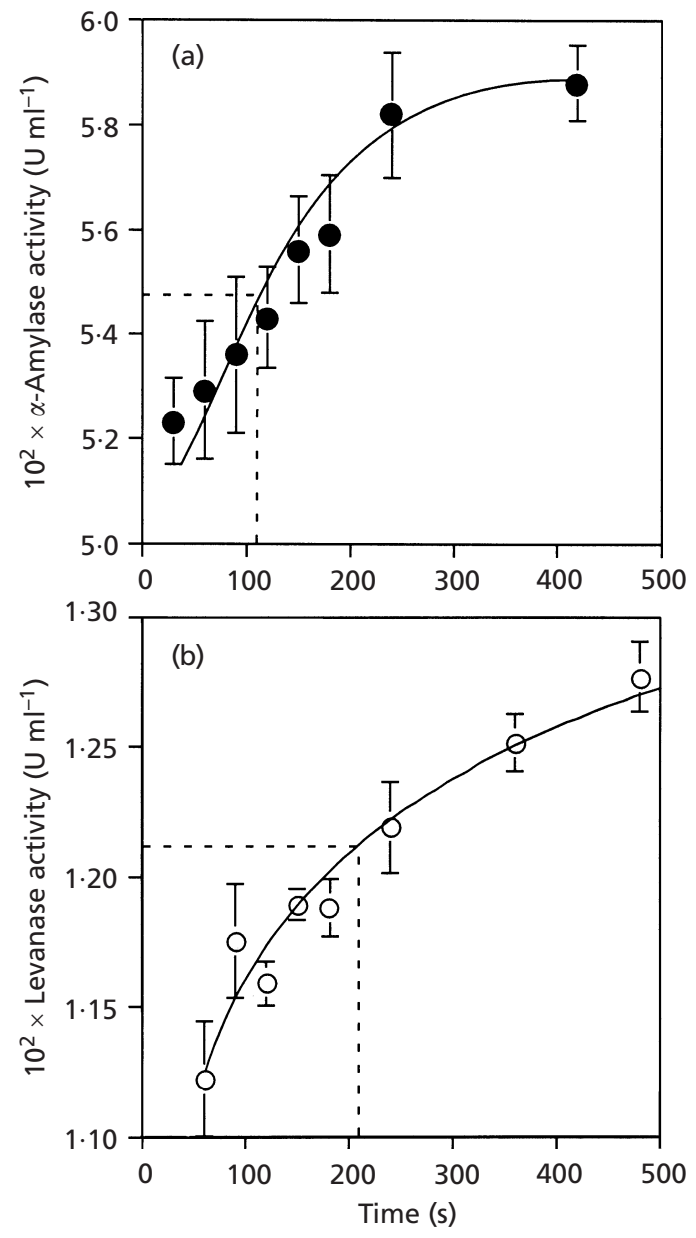

Fig. 6. Determination of the functional decay of amyE (a) and sacC (b) mRNAs. The functional half-lives of amyE and sacC mRNA were determined by quantifying the amount of $\alpha$ amylase and levanase produced at intervals after inhibition of transcription. Cells of strains GM96101 or GM96201 were induced at an $\mathrm{OD}_{600}$ of 2.5 with $60 \mathrm{mM}$ sucrose. After $20 \mathrm{~min}$ induction, rifampicin was added at $100 \mu \mathrm{g} \mathrm{m}^{-1}$ final concentration. Aliquots of cell suspension were removed at time intervals and immediately centrifuged at $2{ }^{\circ} \mathrm{C}$ in the presence of chloramphenicol $\left(100 \mu \mathrm{g} \mathrm{ml}^{-1}\right.$ final concentration). $\alpha$-Amylase or levanase was subsequently assayed in the supernatants. The mean value and the standard deviation of four independent assays of enzyme activity for each sample are plotted as a function of time after addition of rifampicin.

harbouring this fusion, despite the two substitutions in the spacer region (data not shown). From this set of results, we concluded that the modifications introduced in the RBS spacer regions of the various constructs could not account for the discrepancies observed in the stability and in the translational efficiency of their respective mRNAs. We can now discuss other hypotheses.

In prokaryotic cells various factors are known to affect mRNA stability and therefore the steady-state level of the transcript. These factors include both gene-specific characteristics and bulk cellular conditions (Carrier \&
Kiesling, 1997), and can be divided into several categories which we will examine below.

The effects of protein synthesis on mRNA stability include translational initiation and elongation rate as well as codon usage. It has been noted that the expression of proteins can be controlled by codon usage according to the cellular levels of tRNA, which fluctuate with growth conditions and growth phase (Saier, 1995; Shields \& Sharp, 1987; Karlin \& Mrazek, 2000). However, the different gene fusions constructed were all expressed under the same growth conditions and during the same growth phase. Moreover, comparison of codon usage in amyE, sacC and csn showed that it is very similar for all three, but differs greatly from that of $s a c B$ (Nitschké et al., 1998). Thus, a global effect of codon usage is highly improbable, although one should not rule out the possibility of a local effect on the rate of elongation which leaves sites unprotected from endonucleolytic attack.

Moreover, the $5^{\prime}$ untranslated region contains a hairpin (ribonucleic antiterminator sequence) involved in the antitermination mechanism (Crutz et al., 1990; Aymerich \& Steinmetz, 1992) which regulates the transcription of genes under the control of sacR and can protect them, at least partially, from $5^{\prime}$ endonuclease attack (Emory et al., 1992; Bechhofer, 1993). The free energies of stabilization of the four terminators at the 3' end are all very similar, therefore excluding the hypothesis that the differential stability is caused by differences in hairpins, which are supposed to prevent exonucleases from degrading the coding sequence of the mRNA (Higgins et al., 1993). Finally, the reasons for the low stability of $a m y E$ and $s a c C$ transcripts could lie in the translation mechanism adapted to a particular growth phase (Saier, 1995), hence the features of the translation machinery of the exponential phase did not fit well with these transcripts. The double exponential decay of amyE mRNA in addition to the monophasic decay of the corresponding functional mRNA suggests that this mRNA exists in two different states in the cells: one state with a very short half-life, probably either unprotected or only poorly protected by ribosomes, and therefore highly sensitive to endonucleolytic attack, and the other ribosome-bound with a half-life within the same range as that of $s a c B$ and $c s n$ transcripts. A similar hypothesis concerning the coexistence in the cell of functional and inactivated mRNA was proposed by Petersen (1993).

This hypothesis was supported by the effects of a $5^{\prime}$ mRNA stabilizer on the stability of sacC mRNA. The effects strongly depend on the distance between the sequence and the RBS. An increase in levanase production was observed mainly in strain GM96202 (sacRasacC fusion) where the SD sequence was created by punctual mutations and was located at a distance of 34 nt from the RBS without any ATG codon between that could modify the initiation of translation. Such an increase unambiguously correlated with an increase in the steady-state level of mRNA resulting from an 
(a)

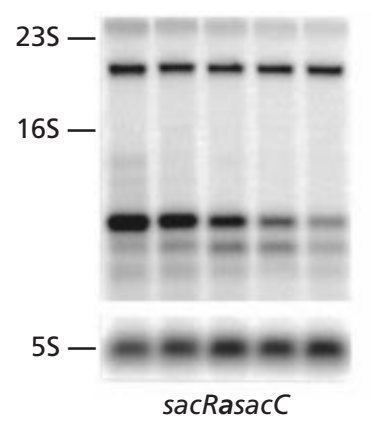

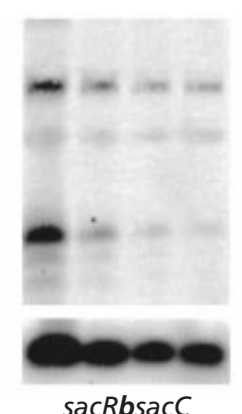

sacRbsacC

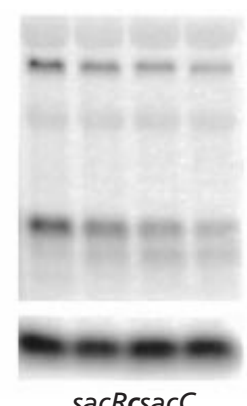

$\operatorname{sacRcsacC}$ (b)

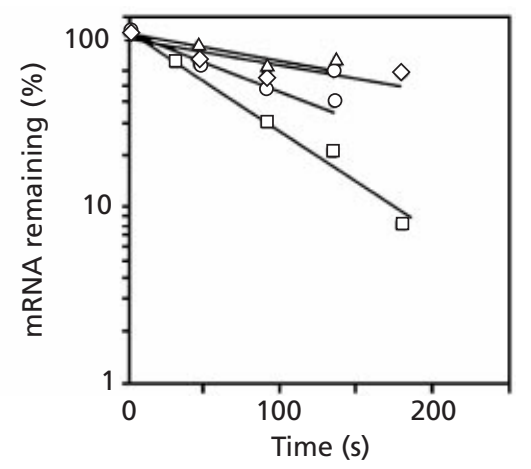

Fig. 7. Kinetic decay of the mRNAs transcribed from the gene fusions of sacRa, sacRb, sacRc with sacC. Cells were grown as described in the legend to Fig. 5. Total RNAs were prepared from samples withdrawn from exponentially growing culture at the indicated times starting $45 \mathrm{~s}$ after the addition of the transcription inhibitor. The gels were loaded with $10 \mu \mathrm{g}$ RNA per lane. Northern blotting analysis was performed with the sacR probe from 0 to $180 \mathrm{~s}$ (a). Quantification of the bands corresponding to the full-length transcripts was carried out as described in Methods. The decays of the fulllength transcripts are represented in (b): $\diamond$, sacRasacC; $\triangle$, sacRbsacC; $O$, sacRcsacC; $\square$, sacRsacC.

Table 5. Half-lives of sacRsacC mutant mRNAs

\begin{tabular}{|c|c|c|c|c|c|c|c|}
\hline \multirow[t]{3}{*}{ Strain } & \multicolumn{4}{|c|}{ Single expontential } & \multirow{3}{*}{$\begin{array}{l}\text { Steady-state levels } \\
\text { (relative ratio) }\end{array}$} & \multicolumn{2}{|c|}{ Secreted levanase production } \\
\hline & \multicolumn{2}{|c|}{ Full length } & \multicolumn{2}{|c|}{ Short mRNA } & & $\mu \mathrm{g}\left(\mathrm{OD}_{600}\right.$ & Relative ratio \\
\hline & $\begin{array}{l}\text { Time constant } \\
10^{2} \times k\left(\mathrm{~s}^{-1}\right)\end{array}$ & $\begin{array}{l}\text { Half-life } \\
\quad(s)\end{array}$ & $\begin{array}{l}\text { Time constant } \\
10^{2} \times k\left(\mathrm{~s}^{-1}\right)\end{array}$ & $\begin{array}{l}\text { Half-life } \\
\quad(s)\end{array}$ & & & \\
\hline $\operatorname{sacRsacC}$ & $1 \cdot 3 \pm 0 \cdot 23$ & $53 \pm 9$ & $1 \cdot 83 \pm 0 \cdot 08$ & $38 \pm 2$ & $1 \cdot 0$ & 0.69 & $1 \cdot 00$ \\
\hline$s a c R a s a c C$ & $0 \cdot 33 \pm 0 \cdot 06$ & $210 \pm 38$ & $1 \cdot 21 \pm 0 \cdot 02$ & $57 \pm 1$ & $3 \cdot 4$ & $2 \cdot 8$ & $4 \cdot 06$ \\
\hline$s a c R b s a c C$ & $0 \cdot 45 \pm 0 \cdot 06$ & $154 \pm 20$ & $2 \cdot 12 \pm 0 \cdot 15$ & $33 \pm 2$ & $2 \cdot 5$ & $0 \cdot 8$ & $1 \cdot 16$ \\
\hline $\operatorname{sacR} \operatorname{csac} C$ & $0.75 \pm 0.09$ & $92 \pm 11$ & $1 \cdot 26 \pm 0 \cdot 04$ & $55 \pm 2$ & $1 \cdot 5$ & $0 \cdot 31$ & $0 \cdot 45$ \\
\hline
\end{tabular}

increase in its stability. The sacRcsacC mRNA steadystate level is slightly increased while the production of levanase is decreased. In this case, the SD sequence was introduced at a distance of $171 \mathrm{nt}$ from the RBS in the very first segment of the transcript. It seems that stalling of ribosomes sterically protects the mRNA and therefore delays degradation, as found previously by Bechhofer $\&$ Dubnau (1987). The cause of decreased protein production is not obvious. In fact the RNA-binding of SacY, the antiterminator protein, in this region (Crutz et al., 1990) complicated our interpretation of the results obtained.

The last point that deserves discussion concerns the accumulation of an apparently homogeneous short transcript obtained with the various $s a c R s a c C$ fusions. Could this be due to a premature release of the RNA polymerase or to $3^{\prime}-5^{\prime}$ degradation?

Both events could result from the presence of a secondary structure in this region (Farr et al., 1999). The prediction obtained from the MFOLD program (Zuker et al., 1999) shows that there is a high probability that this region contains two stem-loops, the first being followed by a sequence rich in A and U (Fig. 8). The calculated free energy of these loops is similar to that of the $\rho$-independent terminators of the four proteins. Finally, the decay of the short transcript is faster than that of the full-length transcript while the proportion of the latter is two times lower. We thus favour the hypothesis that the short transcript results from premature release of the mRNA by the polymerase rather than nuclease degradation.

Taken together, the data presented here attribute an important role to the nucleotide sequence of the structural gene in mRNA stability by influencing the cleavage activities of nucleases. These activities are increased or reduced as a function of ribosome binding protection. Thus, an improvement in the production yield is possible by increasing mRNA stability with an additional SD sequence in the $5^{\prime}$ untranslated region. This possibility needs to be addressed in future studies of $\alpha$-amylase and levansucrase. 


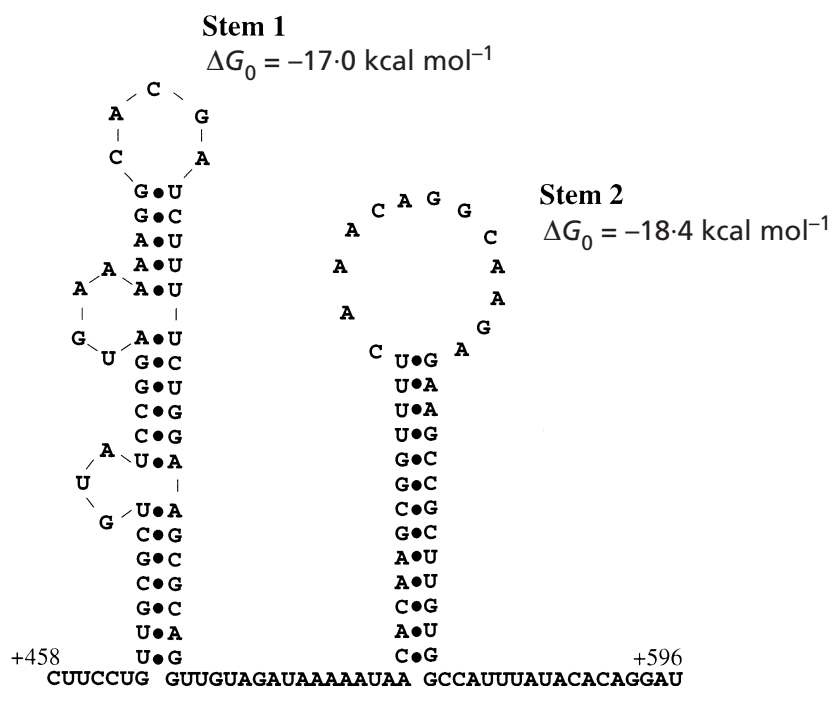

Fig. 8. Terminator-like structure of the $3^{\prime}$ end of sacC short transcript. The secondary structures of the sacC short transcript which represents the folding of minimum free energy was obtained by computer prediction using the MFOLD program (Zuker et al., 1999). Nucleotides are laid out in such a way that paired bases are proximal and the open regions surrounded by single-stranded bases are represented as loops. The free energy $\left(\Delta G_{0}\right)$ of the stems is indicated.

\section{ACKNOWLEDGEMENTS}

We thank Philippe Régnier and members of the European Bacillus Secretion Group for valuable discussions during this work, and Anne-Lise Haenni for helpful comments on the manuscript. We are grateful to Antonia Kropfinger for revision of the English text. Y.P. was supported by a grant from ARC (Association pour la Recherche contre le Cancer). This work was supported in part by grants from the European Commission (Biotech programme, BIO4-CT-96-0097, QLK3-CT1999-00413).

\section{REFERENCES}

Agaisse, H. \& Lereclus, D. (1996). STAB-SD: a Shine-Dalgarno sequence in the $5^{\prime}$ untranslated region is a determinant of mRNA stability. Mol Microbiol 20, 633-643.

Ausubel, F. M., Brent, R., Kingston, R. E., Moore, D. D., Seidman, J. G., Smith, J. A. \& Struhl, K. (editors) (1994). Current Protocols in Molecular Biology. New York: Wiley Interscience.

Aymerich, S. \& Steinmetz, M. (1992). Specificity determinants and structural features in the RNA target of the bacterial antiterminator proteins of the $\mathrm{BglG} / \mathrm{SacY}$ family. Proc Natl Acad Sci US A 89, 10410-10414.

Bechhofer, D. H. (1993). $5^{\prime}$ mRNA stabilizers. In Control of Messenger RNA Stability, pp. 31-52. Edited by J. G. Belasco \& G. Brawerman. London: Academic Press.

Bechhofer, D. H. \& Dubnau, D. (1987). Induced stability in Bacillus subtilis. Proc Natl Acad Sci US A 84, 498-502.

Bechhofer, D. H. \& Wang, W. (1998). Decay of erm C messenger RNA in a polynucleotide phosphorylase mutant of Bacillus subtilis. J Bacteriol 180, 5968-5977.

Bechhofer, D. H. \& Zen, K. (1989). Mechanism of erythromicininduced erm C mRNA stability in Bacillus subtilis. J Bacteriol 171, 5803-5811.
Bouvet, P. \& Belasco, J. G. (1992). Control of RNase E-mediated RNA degradation by $5^{\prime}$ termini base pairing in Escherichia coli. Nature 3, 488-491.

Carrier, T. A. \& Kiesling, J. D. (1997). Controlling messenger RNA stability in bacteria: strategies for engineering gene expression. Biotechnol Prog 13, 699-708.

Chambert, R. \& Petit-Glatron, M. F. (1984). Hyperproduction of extracellular levansucrase by Bacillus subtilis: examination of the phenotype of a $s a c U^{\mathrm{h}}$ strain. J Gen Microbiol 130, 3143-3152.

Chambert, R., Rain-Guion, M. C. \& Petit-Glatron, M. F. (1992). Readthrough of the Bacillus subtilis levansucrase stop codon produces an extended enzyme displaying a higher polymerase activity. Biochim Biophys Acta 1132, 145-153.

Coburn, G. A. \& Mackie, G. A. (1999). Degradation of mRNA in Escherichia coli: an old problem with some new twists. Prog Nucleic Acid Res Mol Biol 62, 55-108.

Condon, C., Putzer, H., Luo, D. \& Grunberg-Manago, M. (1997). Processing of the Bacillus subtilis thrS leader mRNA is RNase Edependent in Escherichia coli. J Mol Biol 268, 235-242.

Crutz, A. M., Steinmetz, M., Aymerich, S., Richter, R. \& Le Coq, D. (1990). Induction of levansucrase in Bacillus subtilis: an antitermination mechanism negatively controlled by the phosphotransferase system. J Bacteriol 17, 1043-1050.

Dion, M., Rapoport, G. \& Doly, J. (1989). Expression of the MuIFN $\alpha 7$ gene in Bacillus subtilis using the levansucrase system. Biochimie 71, 747-755.

Emory, S. A., Bouvet, P. \& Belasco, J. G. (1992). A 5'-terminal stem-loop structure can stabilize mRNA in Escherichia coli. Genes Dev 6, 135-148.

Farr, G. A., Oussenko, I. A. \& Bechhofer, D. H. (1999). Protection against $3^{\prime}$ to $5^{\prime}$ RNA decay in Bacillus subtilis. J Bacteriol 181, 7323-7330.

Higgins, C. F., Causton, H. C., Dance, G. S. C. \& Mudd, E. A. (1993). The role of the $3^{\prime}$ end in mRNA stability and decay. In Control of Messenger RNA Stability, pp. 13-30. Edited by J. G. Belasco \& G. Brawerman. London: Academic Press.

Horionouchi, S. \& Weisblum, B. (1982). Nucleotide sequence and functional map of pC194, a plasmid that specifies inducible chloramphenicol resistance. J Bacteriol 150, 815-825.

Hue, K. K., Cohen, S. D. \& Bechhofer, D. H. (1995). A polypurine sequence that acts as a $5^{\prime}$ stabilizer in Bacillus subtilis. J Bacteriol 177, 3465-3471.

Joliff, G., Edelman, A., Klier, A. \& Rapoport, G. (1989). Inducible secretion of a cellulase from Clostridium thermocellum in Bacillus subtilis. Appl Environ Microbiol 55, 2739-2744.

Joyet, P., Levin, D., de Louvencourt, L., Le Révérent, B., Aymerich, A. \& Heslot, H. (1986). Expression of a thermostable alphaamylase gene under the control of levansucrase inducible promoter from Bacillus subtilis. In Bacillus Molecular Genetics and Biotechnology Applications, pp. 470-491. Edited by A. T. Ganesan \& J. A. Hoch. London: Academic Press.

Kaberdin, V. R., Miczak, A., Jakobsen, J. S., Lin-Chao, S., McDowall, K. J. \& von Gabain, A. (1998). The endoribonucleolytic $\mathrm{N}$-terminal half of Escherichia coli RNase E is evolutionarily conserved in Synechocystis sp. and other bacteria but not the Cterminal half, which is sufficient for degradosome assembly. Proc Natl Acad Sci U S A 95, 11637-11642.

Karlin, S. \& Mrazek, J. (2000). Predicted highly expressed genes of diverse prokaryotes. J Bacteriol 182, 5238-5250.

Kunst, F., Ogasawara, N., Moszer, I. \& 148 other authors (1997). The complete genome sequence of the gram-positive bacterium Bacillus subtilis. Nature 390, 249-256. 
Leloup, L., Haddaoui, E., Chambert, R. \& Petit-Glatron, M. F. (1997). Characterization of the rate limiting step of the secretion of Bacillus subtilis $\alpha$-amylase overproduced during the exponential phase of growth. Microbiology 143, 3295-3303.

Leloup, L., Le Saux, J., Petit-Glatron, M. F. \& Chambert, R. (1999). Kinetics of the secretion of Bacillus subtilis levanase overproduced during the exponential phase of growth. Microbiology 145, 613-619.

Lepesant, J. A., Kunst, F., Pascal, J., Kejzlarova-Lepesant, Steimetz, M. \& Dedonder, R. (1976). Specific and pleiotropic regulatory mechanisms in the sucrose system of Bacillus subtilis 168. In Microbiology-1976, pp. 58-69. Edited by D. Schlessinger. Washington, DC: American Society for Microbiology.

Martin-Verstraete, I., Débarbouillé, M., Klier, A. \& Rapoport, G. (1990). Levanase operon of Bacillus subtilis includes a fructosespecific phosphotransferase system regulating the expression of the operon. J Mol Biol 214, 657-671.

Masson, J. Y., Denis, F. \& Brezinski, R. (1994). Primary sequence of the chitosanase from Streptomyces sp. strain N174 and comparison with other endoglycosidases. Gene 140, 103-107.

Nitschké, P., Guerdoux-Jamet, P., Chiapello, H., Faroux, G., Henaut, C., Henaut, A. \& Danchin, A. (1998). Indigo: a WorldWide-Web review of genomes and gene functions. FEMS Microbiol Rev 22, 207-227.

Oussenko, I. A. \& Bechhofer, D. H. (2000). The yvaJ gene of Bacillus subtilis encodes a $3^{\prime}$-to-5' exoribonuclease and is not essential in a strain lacking polynucleotide phosphorylase. $J$ Bacteriol 182, 2639-2642.

Parro, V., San Roman, M., Galindo, I., Purnelle, B., Bolotin, A., Sorokin, A. \& Mellado, R. P. (1997). A 23911 nucleotide region of the Bacillus subtilis genome comprising genes located upstream and downstream of the lev operon. Microbiology 143, 1321-1326.

Petersen, C. (1993). Translation and mRNA stability in bacteria: a complex relationship. In Control of Messenger RNA Stability, pp. 117-145. Edited by J. G. Belasco \& G. Brawerman. London: Academic Press.

Petit, M. A., Joliff, G., Mesas, J. M., Klier, A., Rapoport, G. \& Ehrlich, S. D. (1990). Hypersecretion of a cellulase from Clostridium thermocellum in Bacillus subtilis by induction of chromosomal DNA amplification. Biotechnology 8, 559-563.

Petit-Glatron, M. F. \& Chambert, R. (1992). Peptide carrier potentiality of Bacillus subtilis levansucrase. J Gen Microbiol 138, 1089-1095.

Priest, F. G. (1977). Extracellular enzyme synthesis in the genus Bacillus. Bacteriol Rev 41, 711-753.

Putzer, H., Gendron, N. \& Grunberg-Manago, M. (1992). Co- ordinate expression of the two threonyl-tRNA synthetase genes in Bacillus subtilis: control by transcriptional antitermination involving a conserved regulatory sequence. EMBO J 11, 3117-3127.

Régnier, P. \& Arraiano, C. M. (2000). Degradation of mRNA in bacteria: emergence of ubiquitous features. Bioessays 22, 235-244.

Saier, M. H., Jr (1995). Differential codon usage: a safeguard against inappropriate expression of specialized genes? FEBS Lett $362,1-4$.

Shields, D. C. \& Sharp, P. M. (1987). Synonymous codon usage in Bacillus subtilis reflects both translational selection and mutational biases. Nucleic Acids Res 15, 8023-8040.

Shimotsu, H. \& Henner, D. J. (1986). Modulation of Bacillus subtilis levansucrase gene expression by sucrose and regulation of steady-state mRNA level by sacU and sacQ genes. J Bacteriol 168, 380-388.

Steege, D. A. (2000). Emerging features of mRNA decay in bacteria. RNA 6, 1079-1090.

Steinmetz, M., Le Coq, D., Aymerich, S., Gonzy-Tréboul, G. \& Gay, P. (1985). The DNA sequence of the gene for the secreted Bacillus subtilis enzyme levansucrase and its genetic control sites. Mol Gen Genet 200, 220-228.

Tominaga, Y. \& Tsujisaka, Y. (1975). Purification and some enzymatic properties of the chitosanase from Bacillus R-4 which lyses Rhizopus cell walls. Biochim Biophys Acta 410, 145-155.

Wang, W. \& Bechhofer, D. H. (1996). Properties of a Bacillus subtilis polynucleotide phosphorylase deletion strain. J Bacteriol 178, 2375-2382.

Wang, W. \& Bechhofer, D. H. (1997). Bacillus subtilis RNase III gene: cloning, function of the gene in Escherichia coli, and construction of Bacillus subtilis strains with altered rnc loci. J Bacteriol 179, 7379-7385.

Wong, S. L. (1989). Development of an inducible and enhancible expression and secretion system in Bacillus subtilis. Gene 83, 215-223.

Yamaguchi, K., Nagata, Y. \& Maruo, B. (1974). Genetic control of the rate of alpha amylase synthesis in Bacillus subtilis. J Bacteriol 119, 410-415.

Zuker, M., Mathews, D. H. \& Turner, D. H. (1999). Algorithms and thermodynamics for RNA secondary structure prediction. A practical guide. In RNA Biochemistry and Biotechnology. Edited by J. Barciszewski \& B. F. C. Clark. NATO ASI Series: Kluwer Academic Publishers.

Received 14 November 2000; revised 22 January 2001; accepted 8 February 2001. 